December 29, 1900.

\section{A METALLIC THERHOMETER}

A mercurial thermometer calls for manipulations which are not within the scope of the amateur, but require the skill and experience of the regular manufacturer. A metallic thermometer, however, is very easily made, and serves the purpose fully as well as a to the variations of temperature as may be desired.

to is made by placing together a strip of steel and one of brass 6 inches long, $1 / 4$ inch wide and $\frac{1}{32}$ inch thick. The ends of the strips are tinned for about $3 / 8$ of an inch at each end on their sijjacent faces, and then put together and heated first at one end and then at the other, so as to solder them together at the ends.

The brass strip is made about $1 / 4$ inch longer than the steel strip, and is bent over and perforated to receive a silk thread as will"be presently explained. Commonly, when strips of steel and brass are used in a compound bar, they are riveted at short intervals, to keep them from buckling. In the present case the compound bar is provided with a winding of soft wire (No. 30) which keeps the strips elose together. To insure permaneney the bars are drilled and riveted with a single rivet at each end.

The compound bar thus made is inserted in a round hole in the middle of a hard-wood block $21 / 2$ inches long, and held there by an ordinary wood-serew inserted in the end of the block and clamping the end of the bar. The wooden block is secured to a base piece, 4 inches square and $7 / 8$ inch thick, having attached to it a back board $1 / 4$ inch thick, 4 inches wide, and about 10 inches high. A wire nail about $\frac{1}{16}$ inch in diameter and $1 \frac{1}{2}$ inches long is driven through the back with its pointed end projecting about $1 \frac{1}{4}$ inches. The nail is about $3 / 4$ inch from the upper free end of the compound bar. A paper roll is formod upon another nail or a piece of wire a trifle larger than the one used in the construction of the thermometer. The strip of writing paper used for this roller should be 1 inch wide and about 8 inches long. Enough of the paper is wound to make the roller $1 / 4 \mathrm{inch}$ in diameter. The paper, except the first layer, is pasted as it is rolled, so that it forms a solid paper roll when it is dry.

This roll, when dry, is transferred to the nail projecting from the back piece, and a pointer, or index, about $2 \frac{1}{2}$ inches long is cut from thick writing paper and glued to the end of the roll. Then a silk thread is tied in the eye in the free end of the compound bar, and passed over the roller on the nail, and wound three times around the roll, and it has attached to it a small weight. In the present case this weight consists of a lead bullet split half open with a knife, and closed down upon the thread by pliers or by hamwerclosed down upon the thread by pliers or by hamwer-
ing. With every change in temperature the compound bar swings, so as to cause a movement of the index by the pulling or releasing of the thread and the raising or lowering of the weight.

The index should be placed in a vertical position when the temperature is about $70^{\circ}$; then the winding of the silk should be separated a little, and a small drop of mucilage should be placed on the middle con. volution of the thread at the top of the roller, so as to cewent it to the roller and prevent any change of adjustment.

A sewicircular piece of bristol board, about 6 iuches in diameter, is tewporarily supported behind the index by a block glued to the back-piece. The bristol board is to form the thermoweter scale and is fastened to the block by tacks or otherwise, so that it can be removed and accurately replaced. A pencilmark is now made on the scale at the point of the index which indicates the temperature as shown by a mercurial thermometer at the time. If it is $70^{\circ}$, the mark on the new scale represents this temperature, and whenever the index points to this mark the observer knows the thermometer is $70^{\circ}$.

Now the thermometer is placed in a refrigerator along with a mercurial thermometer. They are left in the refrigerator for an hour, and then a pencil mark is made at the point of the index. This will, perhaps, be $40^{\circ}$. 'The space between these two marks is divided into thirty even spaces, representing as many degrees, or. it may be divided into fifteen spaces, each of which will represent $2^{\circ}$. This graduated space serves as a guide for constructing the balance of the scale. If $2^{\circ}$ spaces are used, twenty such spaces laid off on the left-hand side of the scale will extend the scale to zero. Twenty more such spaces will extend the scale to $40^{\circ}$ below zero, which is lower than any temperature experienced in this climate. The space between $40^{\circ}$ and $70^{\circ}$ is already graduated, and the space above the $70^{\circ}$ mark is gradu

\title{
Srientific Amenucau.
}

ated as described for the lower end of the scale. As euch line represents $2^{\circ}, 10^{\circ}$ would be represented by ive lines, so that the fifth line could be extended beyond the other lines for the sake of convenience in reading. Figures from $0^{\circ}$ are placed opposite the lon lines so as to read $10^{\circ}, 20^{\circ}, 30^{\circ}, 40^{\circ}$, and so on, as in an ordinary therwoweter scale.

The amateur can refine this thermometer as much as he pleases. He may, if he desires, place the entire device in a case and cover the dial with a glass, providto enable the air to circulate and thus keep the temperature the same as that of the externa
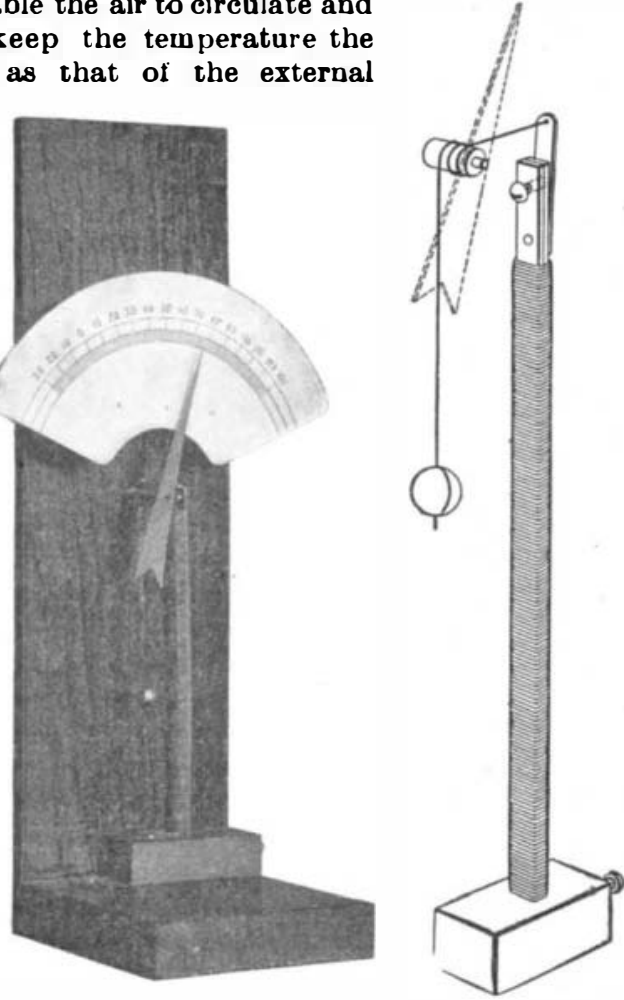

A METALLIC THERMOMETER

air. The free end of the compound bar may have a spring riveted to it, as shown in the detached view, and an adjusting serew may be inserted in the com pound bar so as to bear against the spring. With this construction, the silk thread way be tied in a hole in the free end of the spring, and the desired adjustment may be made by turning the serew one way or the

By making the compound bar longer, or diminishing the diameter of the cylinder around which the thread extends, or both, the sensitiveness of the instrument may be greatly increased.

\section{SOME CORIOUS SCULPINS.}

The accompanying illustration is the attempt for the first time to photograph one of the Californian sculgrapher were directed to obtaining a front view, but the fish rose and was wriggling through the water when taken, giving an excellent view of its grotesque head and enorwous pectoral fins, which seem in these fishes and their allies to constitute legs rather than fins, a in moving along the bottom they are used as such. ed he furnishes several apertures pins in its native element. The efforts of the photo-

At this time they were all mottled in coloring, white and gray predowinating, with here and there $a$ dash of yellow, and when resting on the bottom they were ver inconspicuous, and as their habit was to remain perfectly quiet wuch of the time, it was not always easy to distinguish them. There was one telitale, howeve - the beautiful eye, which burned and blazed like topaz in the bright light; and when the sunbeams, fell upon the group of sculpins, the bottom seemed to be dotted with gems.

When the sculpins-Scorpæna guttata-were released into the arranged tanks, they all offered a more or less decided contrast, and it was an interesting sight to see them adapt themselves to the new conditions. The scujpins which were released on the white bottom apparently found at once that they were in an unenviabla position, presenting a striking contrast to the bottom, with no rocks awong which to hide. That the fishes appreciated the situation there could be little doubt, as they moved restlessly about, rising frow the bottom with a wriggling motion; and then began the warvelous change which Nature has made possible. They very gradually faded out; no other terw expresses it. The distinct dark or black spots became light brown, then gray, then a very light gray, and as I watched them they seemed to melt, as it were, into the sand, becoming less and less conspicuous until finally in an hour or so after they had been placed in the tank they were so indistinct that a few feet away they would have been considered stones instead of fishes. They never assumed a perfectly white disguise, this was apparently impossible; a very light gray or a dirty white was the extent of the effort to assimilate the surroundings, and as a protective movement it was practically a success.

In the fishes which did not offer so great a contrast to their artificial surroundings there was not so marked a change, yet it was more perfect in the sense of being a protection; and in the case of the dark gray and mottled fishes it required a keen eye to distinguish the color of the fbodies ffrom that of the surroundings in an hour after the change. Later the sculpins were changed about, the one on the white bottom to a black base, where in time the protective hue was assumeda defense purely of Nature's designing, which protects the most delicate of animals from their foes. To the average observer it would appear that the fish perceived its danger and proceeded to change its color so that it would become inconspicuous, but that the fish was conscious of the change is far from the truth. The wonderful change in the appearance of the fish took place really without the knowledge of the animal, being due to the color of its surroundings. The term chromatic function is applied to this adaptation of color, and can be better understood by the layman by an examination of the skin of some animal susceptible of change of color. A sectional view of the skin of a frog will show two layers, the epidermis and cutis. The latter contains many large glands filled with color, or pigment. These pigment glands,| or chromatophores, are exceedingly sensitive; the slightest change in the color, or perhaps the intensity, of a ray of light will cause thein to expand or contract. Some are brown, some red, green, black or yellow, and the colors are subject to certain variation. Heincke found that glands which were yellow when distended became orauge under reverse conditions; and cells which were orange, when expanded became black when contracted. Near the epidermis, in the cutis, the investigator will find masses of very light yellow pigment glands. Under,them will be seen masses of red or brown, and deeper still layers of jet-black color glands. Exactly how the pigment layers produce such perfect and it is but just to state there are many theories. But certain facts are known which suggest the plausibility of the theory here presented. It has been found that if a complete relaxation of all the chromatophores occurs, the prevailing color of the animal will be black or a very dark brown, depending upon the animal. It was long supposed that light or color rays striking the body of the animal produced the contraction and expansion necessary to change, but finally Pouchet discovered that blind animals rePHOTOGRAPH FROM LIFE OF A CALIFORNIA SGOLPL,

The sculpin is the cowmon form of the shallows at Santa Catalina Island, and is particularly interesting on account of its marvelous mimicry. The writer kep twenty or more of these fishes in confinement during period of several months, with the view of testing their power of adapting themselves to their surroundings a a protection. For this purpose several tanks were arranged; one having a white bottom, another one of black, while two others represented various grades be tween them. Into these the sculpins were liberated. mained the same color under all the medium, these organs receiving the impression, which passes by the sympathetic nerves to the color cells all over the body, causing some to contract, others to expand, so producing a harmonious color scheme in the animal; in :a word, producing an assimilation in tint between it and immediate surroundings. No more marvelous page in the book of Nature exists than changes the protection of innumerable defenseless circumstances, which demonstrated that the eye was this, which determines by a most intricate series of 